ESJ Natural/Life/Medical Sciences

\title{
Paleoenvironments and Hydrocarbon Potential of Upper Cretaceous Shales in Agbabu-1 Well, Dahomey Basin SW Nigeria
}

Adekeye Olabisi Adeleye, Department of Geology and Mineral Sciences, University of Ilorin, Nigeria Ogundipe Olumide, Department of Geology and Mineral Sciences, University of Ilorin, Nigeria Adeoye James Adejimi,

Department of Geology and Mining, Ibrahim Badamasi Babangida

University, Lapai, Niger State, Nigeria

Adeyilola Adedoyin,

Central Michigan University, Mount Pleasant, Michigan, North Dakota, USA

Samuel Olukayode, University of Newcastle, upon Tyne, UK

Akande Samuel Olusegun, Department of Geology and Mineral Sciences, University of Ilorin, Nigeria

Doi:10.19044/esj.2021.v17n43p194

Submitted: 24 July 2021

Accepted: 14 October 2021

Published: 31 December 2021
Copyright 2021 Author(s)

Under Creative Commons BY-NC-ND 4.0 OPEN ACCESS

Cite As:

Adekeye O. A., Ogundipe O., Adeoye J. A., Adeyilola A., Samuel O.,\& Akande S. O.,(2021). Paleoenvironments and Hydrocarbon Potential of Upper Cretaceous Shales in Agbabu-1 Well, Dahomey Basin SW Nigeria European Scientific Journal, ESJ, 17(43), 194.

https://doi.org/10.19044/esj.2021.v17n43p194

\begin{abstract}
Upper Cretaceous shales partially exposed in the northern fringes of the Dahomey Basin are well developed in the subsurface in Southwestern part of the basin where Agbau-1 well is sited. These shales were evaluated in respect to their paleoenvironments and potentials for hydrocarbon using foraminiferal assemblages, biomarkers and Rock Eval pyrolysis studies. The dominance of benthonic foraminifera species suggests a shallow marine environment and high percentage of calcareous to arenaceous benthic foraminifera indicate high water salinity and hypersline environment. Dysoxic oxygen condition is also prevalent probably because most of the benthic
\end{abstract}


foraminifera recovered are epifauna that live in a reduced oxygen condition. $1.90 \mathrm{wt} \%, 244 \mathrm{mgHC} / \mathrm{gTOC}$ and $429^{\circ} \mathrm{C}$ average values of total organic carbon, hydrogen index and Tmax reveal that the Upper Cretaceous shales have relatively fair to good organic matter, predominantly Type II-III kerogen and currently immature. Though three is a trend of an increase in maturity down the hole. All the steranes have uniform distributions (C27>C28>C29), suggesting a relatively higher input from the marine red algae and a low level of land plant contribution to the source organic matter. Pristane/phytane ratios and C29/C27 steranes confirmed the organic matter type to be a Type II/III and anoxic source rock depositional condition as well as a reducing diagenetic system in the sediment water column. The Upper Cretaceous shales in Dahomey Basin can be targeted for exploration as an unconventional petroleum resource.

\subsection{Introduction}

Hydrocarbon production from the prolific Niger Delta basin has been the most valuable source of income and energy in Nigeria. However, hydrocarbon resources are being depleted daily and the need to explore more hydrocarbon plays have never been more important. Rigorous exploration activities in the adjacent frontier basins and deeper Cretaceous plays are among the few options of supplementing the depleting Niger Delta resources. The discovery of oil in offshore Cretaceous sediments of the Ise Formation in the Gulf of Guinea has increased the study and search for oil in the eastern Dahomey Basin. The source rock within this formation has a Type I kerogen with a Total Organic content of $4 \%$ and hydrogen index (HI) greater than 500 g/gram (Brownfield and Charpentier, 2006). Lower Cretaceous lacustrine source rocks with kerogen within the oil windows were identified in the far west of Ivory Coast basin (Elvsborg and Dalode, 1985; Abacan-Addax Consortium, 1998). Further studies on two Cenomanian shales samples in the underlying Abeokuta Formation (presents day Afowo formation) by (BeicipFranlab, 1994 and Adeoye et al., 2020) showed a TOC range of 4.2 and 7.1 wt.\% with HI values of 324 and $531 \mathrm{mg} \mathrm{HC/gTOC}$ as potential resources for more discovery of oil and gas to increase the national reserve.

The eastern section of the Dahomey basin also contains more hydrocarbon resources in term of extensive tar sand deposits within the Abeokuta Group (Ise, Afowo and Araromi Formations), which extends over a belt of $120 \mathrm{~km}$ long (Enu, 1987). Ekweozor and Nwachukwu (1989) and Ekweozor and Telnaes (1990) examined the origin and composition of the tar sand from the Abeokuta Group. 
Adekeye and Akande, (2010) had contributed information on some geochemical properties of Upper Cretaceous sequences from the Gbekebo and Araromi borehole. This present study aims to evaluate the paleoenvironments and hydrocarbon potential of the Upper Cretaceous shales in Agbabu-1 well through foraminiferal paleontological, Rock Eval pyrolysis, and biomarker characterization to assess their possible contribution to the petroleum resources of the basin be it conventional or unconventional.

\subsection{Geologic Setting}

Dahomey Basin is part of the West African margin sag basin system (Klemme 1975; Kingston et al., 1983). The rifting and opening up of Gulf of Guinea through the separation of the African and South American plate is connected to the evolution of the basin (Storey, 1995; Mpanda, 1997). It is a coastal sedimentary basin that is adjacent to the present-day Gulf of Guinea and extends from southeastern Ghana, along Togo, Benin and Southwestern Nigeria (Burke et. al., 1971). The boundaries are defined on the western flank by the Ghana ridge and extensions of the Romanche fracture zones, on the eastern flank they are bounded by the Benin hinge line. The hinge line separates the Okitipupa ridge from the adjacent Tertiary Niger Delta (Adegoke 1977, Elvsborg and Dalode, 1985; Omatsola and Adegoke, 1981). Massive deposition of thick non-marine sediments accompanied the late Jurassic and early Cretaceous rifting and graben formation and these sediments in combination with the basement floor, block faulted and further created a series of horst and graben (Omatsola and Adegoke, 1981). Hessouh et al., (1994) worked on seismic data and subsurface structural models to understand the tectonics and sedimentary history of some parts of the Dahomey basin. They divided the tecno-sedimentary into four (4) stages from the oldest to youngest as: pre-rift (up to late Jurassic), syn-rift (Neocomian to lower Cretaceous), transitional (Cenomanian to Santonian) and post-rift (Maastrichtian to Holocene). (Adegoke, 1969; Ogbe, 1970; Kogbe, 1974; Billman, 1976; Omatsola and Adegoke, 1981; Ako et al., 1980; Okosun, 1990; Idowu et al., 1993; Adekeye, 2005 and Adekeye et al., 2006) have studied the stratigraphic framework, sedimentology and depositional settings of the Dahomey basin (Fig. 1). They identified five formations within the Cretaceous and Tertiary ages. The formations from the base to top include: Abeokuta Group comprises of Ise, Afowo and Araromi Formations (Cretaceous), Ewekoro Formation (Paleocene), Oshosun Formation (Eocene) and Ilaro Formation (Eocene) (Fig. 2). This work examines the Araromi Formation, which is mainly a shale lithology with thin intercalations of marl and limestone (Omatsola and Adegoke, 1981). The shale is grey to black and has a high organic content 
with beds of lignite at the shallow depth. The formation is similar in composition to the Nkporo shale and does not outcrop anywhere within the basin (Okosun 1990). (Jan du Chene, 1977, Adegoke et al., 1980) assigned a Maastrichtian to Paleocene age to the Araromi Formation with respect to its fossil contents.

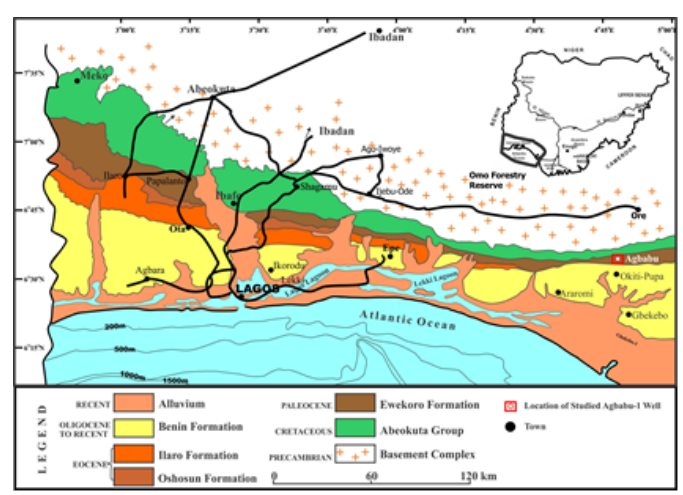

Fig. 1. The outline geological map of Dahomey Basin (Modified after Adekeye et al., 2019)

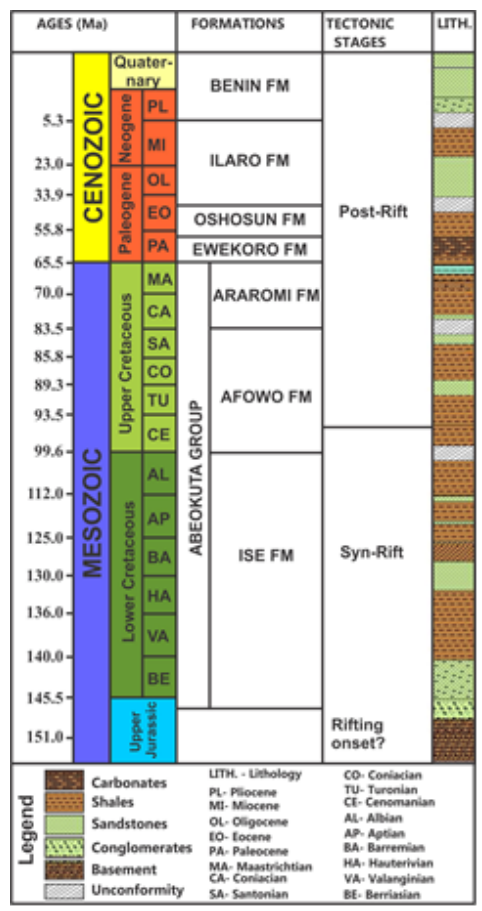

Fig. 2. Chronostratigraphic chart of the Dahomey Basin showing key tectonic stages in relation to the geologic formations and lithologies (Modified from Adeoye et al., 2020)

\subsection{Methodology}

\subsection{Rock Eval Pyrolysis}


Twenty (20) drill cuttings samples were collected within the interval $1128 \mathrm{~m}$ to $2181 \mathrm{~m}$ from the Agb_1 well in the eastern part of Dahomey basin in Southwestern Nigeria. The samples were crushed and pulverized into a 250 microns mesh (US mesh 60) in preparation for the analysis. About $60-80 \mathrm{mg}$ of the pulverized samples were transferred into the crucibles in the UNDWeatherford Source Rock Analyzer. The first crucible in the sequence is blank, this is done to allow the machine perform a blank correction for all the subsequent samples in the crucibles. The analysis involves loading of a standard sample after every five (5) samples, to ensure quality assurance and quality of results. Operating procedures for programmed Rock-Eval pyrolysis involves heating $60-80 \mathrm{mg}$ of pulverized samples at $300^{\circ} \mathrm{C}$ for 3 minutes, followed by programmed pyrolysis at $25^{\circ} \mathrm{C} / \mathrm{min}$ to $650^{\circ} \mathrm{C}$ in a helium atmosphere (Clementz et. al., 1979). Hydrocarbons liberated from the samples during pyrolysis are detected by a flame ionization detector (FID) within the equipment. The various measurements determined from rock eval pyrolysis includes $\mathrm{S}_{1}, \mathrm{~S}_{2}, \mathrm{~S}_{3}$, TOC, Tmax, OI, HI, PI

\subsection{Extraction and Fractionation}

Samples from the Araromi well were crushed and pulverized in a rotary mill. The powdered samples were then soxhlet extracted in preextracted cellulose thimble with azeotropic mixture of redistilled dichloromethane/methanol (93:7, v/v) for 24hours. Copper turnings were added to remove the elemental sulphur in the samples. An aliquot of the total extractable organic matter (EOM) for each sample was fractionated into aliphatic and aromatic hydrocarbons, and NSO/resin fractions by thin layer chromatography (TLC, Kieselgel 60G,) using petroleum ether as the developer. The separated aliphatic and aromatic hydrocarbon fractions were submitted for GC and GC-MS analyses.

\subsection{Gas chromatography (GC)}

GC was carried out on the aliphatic hydrocarbon fractions for their $n$ alkane distribution using an HP 5890 series II GC fitted with HP-5 fused silica capillary column $(30 \mathrm{~m} \times 0.25 \mathrm{~mm}$ i.d., $0.25 \mu \mathrm{m}$ film thickness). The oven was programmed to run at $50^{\circ} \mathrm{C}(2 \mathrm{~min})$ and the temperature was ramped from $50^{\circ} \mathrm{C}$ to $300^{\circ} \mathrm{C}$ at $4^{\circ} \mathrm{C} / \mathrm{min}$, followed by a $20 \mathrm{~min}$ isothermal condition at $300^{\circ} \mathrm{C}$. Hydrogen was used as the carrier gas at a flow of $2 \mathrm{~mL} / \mathrm{min}$.

\subsection{Gas Chromatography-Mass Spectrometry (GC-MS)}


GC-MS analysis of aliphatic and aromatic fractions was performed on a Hewlett Packard $6890 \mathrm{GC}$ split/splitless injector $\left(280^{\circ} \mathrm{C}\right)$ linked to a Hewlettpackhard 5973 mass selective detector (electron voltage $70 \mathrm{eV}$, filament current 220 ųA, source temperature $230^{\circ} \mathrm{C}$, quad temperature $150^{\circ} \mathrm{C}$, multiplier voltage $2500 \mathrm{~V}$, interface temperature $310^{\circ} \mathrm{C}$ ). The acquisition was controlled by a HP Kayak chemstation computer, initially in full scan mode (TIC; 50$550 \mathrm{amu} / \mathrm{sec}$ ) or in selected ion mode (SIM; 30 ions $0.7 \mathrm{cps} 35 \mathrm{~ms}$ dwell) for greater sensitivity. The sample (1ul) in methylene chloride was injected by an HP7683 auto sampler and the split opened after 1 minute. After solvent peak had passed the GC, temperature programme and data acquisition commenced. Compounds separation was performed on a fused silica capillary column (60m x $0.25 \mathrm{~mm}$ i.d.) coated with $0.25 \mu \mathrm{m} 5 \%$ phenyl dimethyl Polysiloxane (HP-5). The GC was temperature programmed from $40^{\circ} \mathrm{C}$ to $300^{\circ} \mathrm{C}$ at $4^{\circ} \mathrm{C} / \mathrm{min}$ and held at $300^{\circ} \mathrm{C}$ for 20 min with Helium as the carrier gas (flow $1 \mathrm{~mL} / \mathrm{min}$, initial pressure of $50 \mathrm{kPa}$, split at $30 \mathrm{~mL} / \mathrm{min}$ ).

\subsection{Gas Chromatography Mass Spectrometry/ Mass Spectrometry (GC- MS/MS)}

GC-MS/MS was performed on the aliphatic fractions of sample Ar145 using a Varian 1200 quadrupole MS/MS fitted with an HP-5 MS (5\% phenyl di methyl polysiloxane) fused silica capillary column $(30 \mathrm{~m} \times 0.25 \mathrm{~mm}$ i.d. $\mathrm{x} 0.25 \mu \mathrm{m}$ film thickness. The GC separated components were transferred via the heated transfer line to the ion source. Electron impact mode was used for ionisation at $70 \mathrm{eV}$. The oven temperature programme was $40^{\circ} \mathrm{C}(0 \mathrm{~min})$, ramped from $40^{\circ} \mathrm{C}$ to $175^{\circ} \mathrm{C}$ at $10^{\circ} \mathrm{C} / \mathrm{min}$ (held for $1 \mathrm{~min}$ at $175^{\circ} \mathrm{C}$ ), $175^{\circ} \mathrm{C}$ to $225^{\circ} \mathrm{C}$ at $6^{\circ} \mathrm{C} / \mathrm{min}$ (with a hold of $1 \mathrm{~min}$. at $225^{\circ} \mathrm{C}$ ) and then ramped to $300^{\circ} \mathrm{C}$ at $4^{\circ} \mathrm{C} / \mathrm{min}$ with an isothermal condition of $20 \mathrm{~min}$ at $300^{\circ} \mathrm{C}$.

\subsection{Foraminiferal Palaeontology}

The Twenty (20) cuttings from Agbabu- 1 well were digested in the laboratory using hydrogen peroxide $\left(\mathrm{H}_{2} \mathrm{O}_{2}\right)$ and water $\mathrm{H}_{2} \mathrm{O}$ in the ratio of 3:1. The solution was transferred into each of the samples in labelled containers and soaked for twenty-four hours to ensure proper digestion. The digested samples were washed through a 0.63 -micron sieve under a jet of running water until all the clay particles are completely removed. The samples were carefully transferred back into the containers, filled with water, allowed to settle before decanting. The samples were dried on a hot plate and transferred into labelled envelops. A Reflected Light Microscope (RLM) was used in picking the microfossils from the washed residues. This is done by spreading a small quantity of the dried sample evenly on a picking tray. The foraminifera 
content was carefully picked with the aid of a picking brush and transferred into the cellules. The cellules were labelled according to their depths and covered with cover slips to prevent the loss of the specimen.

\subsection{Results And Discussions}

\section{1paleoenvironments}

\subsubsection{Foraminiferal Assemblages}

The distribution of foraminifera may vary according to various combined factors such as substrate type, light intensity, water temperature, food availability oxygen, salinity and current energy according to Murray and Wright (1974). Many of these factors vary with water depth, so depth may capture variations in these parameters and in species distributions. Few planktonic and reasonable number of benthic number of foraminifera were identified and picked from the samples. The planktonic foraminifera species which were identified include; Globotruncanella petaloidea, Globotruncana gansseri, Globotruncana navaroensis,Gobotruncana aegytiaca, Heterohelix globulosa and Abathomaphalus mayaroensis. The Benthic foraminifera species which were identified include; Afrobolivina afra, Nonionella auris., bolivina Africana, Ninion sp., Bolivina explicate, Valvulineria sp.,Texrtularia $h^{o c}$ kleyensis, Cyclammina cancellata, Haplophragmoides sp., and Ammobaculites sp. Fig. 3 showed some of the planktonic and benthonic foraminifera species identified. Results from individual foraminifera counts are eight (8) planktic, thirty-one (31) calcareous and eighteen (18) Arenaceous (Fig. 4). These results showed that the calcareous foraminifera species were abundant and diverse at the deeper part of the well while the arenaceous foraminifera species dominates the shallow portion of the well (Fig. 4). The total distribution for the planktonics, calcareous and arenaceous foraminifera counts is $14 \%, 54 \%$ and $32 \%$ respectively. 


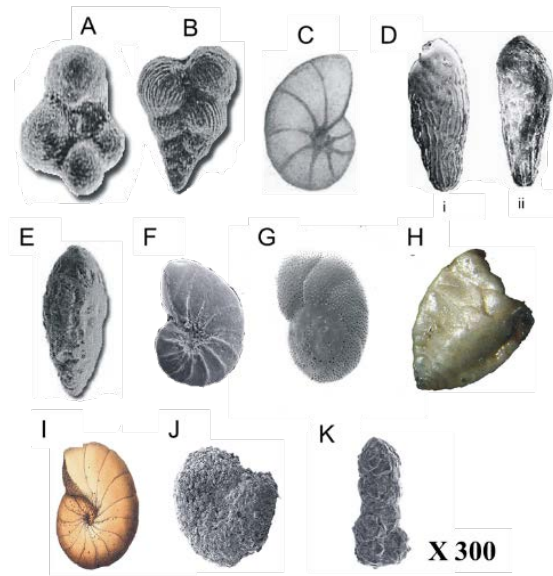

Fig. 3. Photomicrograph of some of the foraminifera identified. (A) Globotruncanella petaloidea (B) Heterohelix globulosa (C) Nonionella auris (D) $\{\mathrm{i}\}$ Afrobolivina afra $\{$ ii $\}$ Bolivina Africana (E) Bolivina explicata (F) Nonion sp (G) Valvulineria sp (H) Textularia hockleyensis (I) Cyclammina cancellata (J) Haplophragmoides sp (K) Ammobaculites sp

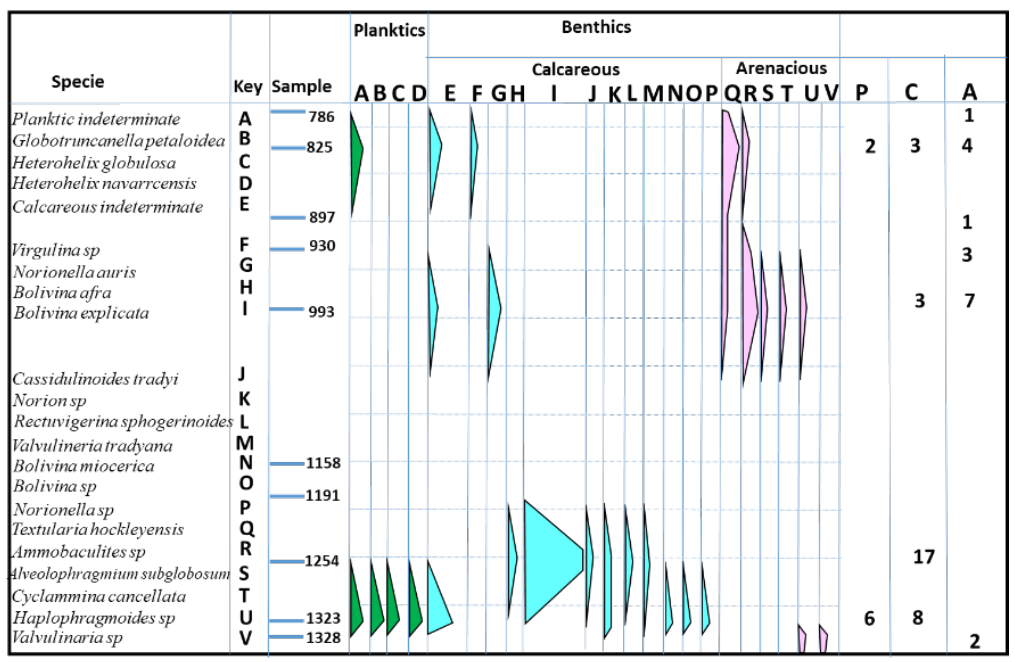

Fig. 4. Recovered planktonics and benthonics foraminifera and count/depth of species in the Agbabu-1 Well

\subsubsection{Benthic Foraminifera and Paleoecology}

The paleoecology interpretation of ancient sediments has been made possible with the aid of benthic foraminifera occurrence, which indicate a wide range of possible water depth which the fossil could withstand (Gebhardt, 2004). This is carried out by correlating modern ecological settings and their fauna, although it is believed that some taxa have changed their environmental preference through time. Species diversity is another general indicator of how 
conducive the environment may be from some foraminifera taxa to populate. Low number of species suggest environmental stresses while high diversity suggests favourable conditions (Murray and Wright, 194). The occurrence of diagnostic benthic species all the definition of minimum and maximum water depth for different part of the well section. High diversity of arenaceous foraminifera indicate low-oxygen concentrations (Gebhardt, 1998). This could be a result of increased input of organic matter from incoming fluvial systems. The shell type such as; Agglutinated, Porcelaneous calcareous and Hyaline calcareous ratio is used in salinity interpretation (Murray and Wright, 1974). The ratio of these test types has been used in differentiating brackish from hypersaline and normal marine environments.

In reconstructing bottom water oxygenation benthic foraminifera assemblages are used. Deep ocean oxygen concentration has a profound impact on marine benthic foraminifera distribution pattern in modern and ancient oceans. As global temperature rise, areas of oxygen-poor environments, which include Oxygen Minimum Zones (OMZs), are predicted to increase, and with this, foraminifera show preference to varying oxygen condition. Many researchers that use foraminifera to evaluate bottom water oxygen (BWO) concentrations consider epifaunal species as indicators of well-oxygenated environments (Kaiho, 1999). The benthic foraminifera are grouped into oxygen indicator categories that is; oxic, suboxic and dysoxic. Deep infauna taxa dominate organic-rich, oxygen depleted environment is regarded as indicators for oxygen depleted environment (Bernhard, 1986). Based on these paleoecologic interpretations of different authors, sediments in this present work are suggested to be deposited in a shallow marine environment due to the dominance of benthonic foraminifera species. Also, the percentage of calcareous to arenaceous benthic foraminifera in the well (Fig. 4) is relatively high and this is an indication of high water salinity and hypersaline environment. The oxygen condition suggests a dysoxic condition because most of the benthic foraminifera recovered are epifauna that live in a reduced oxygen condition.

\subsubsection{Depositional Condition}

Pristane and phytane are isoprenoids that are commonly used to infer depositional conditions for organic rich sedimentary rocks as well as oils derived from those rocks because of the difference in their diagenetic fate under anoxic and oxic conditions. Phytane formation from the phytol side chain of chlorophyll-a is favoured under a reducing condition (low Eh) while oxic condition (high Eh) favours formation of pristane from the same phytol precursor. In keeping to this theory, the depositional conditions for these 
samples have been inferred from the pristane and phytane ratios. Most of the samples generally have pristane/phytane ratio between $0.8-1.2$ (Table 2) suggesting that the organic matter type is likely to be a Type II/III or II-S and anoxic source rock depositional condition as well as a reducing diagenetic system in the sediment water column (Didyk et. al., 1978; Volkman and Maxwell 1986). A plot of these pristane/phytane ratios against $C_{29} / C_{27}$ steranes permits a visual assessment of the organic matter type as well as the depositional condition (Fig. 5) for the Araromi shale samples assessed in this work.

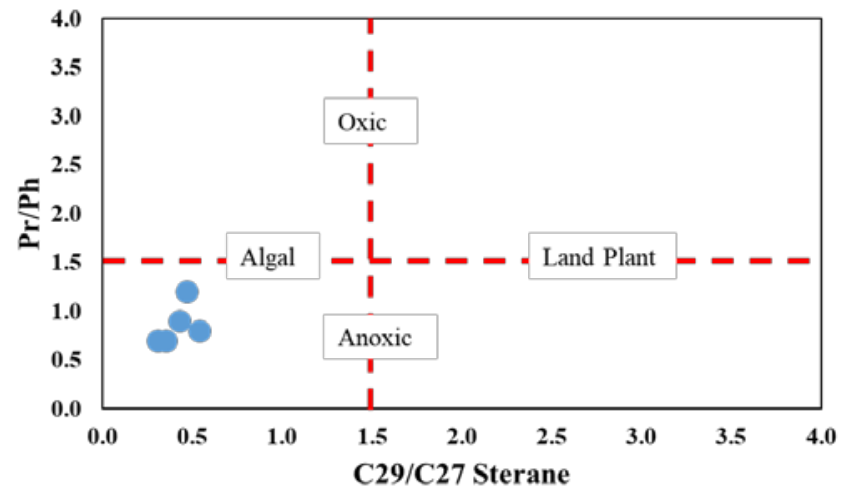

Fig. 5. Plot of $\mathrm{Pr} / \mathrm{Ph}$ against the $\mathrm{C}_{29} / \mathrm{C}_{27}$ sterane used as an estimate of the redox state and predominant organic matter type from the isoprenoids and steranes. All the samples plot in the anoxic and algal dominated zone. Note boundaries are not definitive

It is noteworthy to add that the copper turnings that were recovered from the EOM after the 24-hour period of extraction turned black completely for most of these samples This is an indication of the high sulphur content present in these samples. Although sulphur content was not measured directly, this is an 'informed' measurement of sulphur level as either low or high in a source rock extract. Sulphur incorporation into organic matter occurs during diagenesis by a microbially -mediated (desulfovibrio bacteria) sulphate reduction process under a low Eh condition (Peters et. al., 2005). Further, this observation of high sulphur in addition to the calculated pristane and phytane ratios supports a highly reducing depositional condition for these samples. The low thermal level of maturation for the sample set do not permit the measurement of the homohopane index which may further lend weight to the inferred redox condition from the isoprenoid ratios.

\subsection{Hydrocarbon Potential}

Rock Eval Pyrolysis and biomarker data from the shales from Agbabu1 well were evaluated to determine the quantity, types, depositional condition 
and thermal maturity of organic matter in the Upper Cretaceous sequence as presented in Table 1 and Table 2.

Table 1. Rock-Eval pyrolysis data for the Araromi Formation source rocks in Agbabu-1 Well

\begin{tabular}{|l|c|c|c|c|c|c|c|c|c|c|}
\hline Depth & TOC & $\mathrm{S}_{1}$ & $\mathrm{~S}_{2}$ & $\mathrm{~S}_{3}$ & Tmax & $\begin{array}{c}\text { Calc. } \\
\text { \%Ro }\end{array}$ & $\mathrm{HI}$ & $\mathrm{OI}$ & $\mathrm{PI}$ & $\mathrm{S}_{1}+\mathrm{S}_{2}$ \\
\hline 1128 & 2.06 & 1.54 & 4.67 & 1.01 & 419 & 0.38 & 198 & 34 & 0.25 & 6.21 \\
\hline 1158 & 2.31 & 1.44 & 4.82 & 0.75 & 418 & 0.36 & 215 & 32 & 0.23 & 6.26 \\
\hline 1191 & 1.86 & 1.97 & 4.40 & 0.73 & 422 & 0.44 & 246 & 29 & 0.31 & 6.17 \\
\hline 1224 & 1.84 & 1.56 & 4.66 & 0.67 & 429 & 0.56 & 275 & 36 & 0.25 & 6.36 \\
\hline 1254 & 1.87 & 1.43 & 4.47 & 0.65 & 422 & 0.44 & 273 & 33 & 0.24 & 6.25 \\
\hline 1287 & 1.78 & 1.23 & 3.48 & 0.81 & 432 & 0.62 & 196 & 46 & 0.26 & 4.71 \\
\hline 1323 & 1.98 & 2.08 & 4.18 & 0.83 & 427 & 0.53 & 276 & 42 & 0.33 & 6.26 \\
\hline 1353 & 1.62 & 2.57 & 4.25 & 0.55 & 426 & 0.51 & 220 & 34 & 0.38 & 6.82 \\
\hline 1389 & 1.67 & 1.45 & 3.52 & 0.62 & 427 & 0.53 & 211 & 37 & 0.29 & 4.97 \\
\hline 1419 & 1.73 & 2.58 & 4.13 & 0.44 & 426 & 0.51 & 268 & 25 & 0.38 & 6.71 \\
\hline 1578 & 0.97 & 2.06 & 4.54 & 0.63 & 429 & 0.56 & 253 & 39 & 0.31 & 6.60 \\
\hline 1608 & 0.74 & 1.53 & 3.24 & 0.18 & 432 & 0.62 & 248 & 24 & 0.32 & 4.77 \\
\hline 1665 & 0.96 & 1.50 & 4.27 & 0.41 & 433 & 0.64 & 239 & 43 & 0.26 & 5.77 \\
\hline 1695 & 1.48 & 1.84 & 5.08 & 0.39 & 427 & 0.53 & 212 & 26 & 0.27 & 6.92 \\
\hline 1728 & 1.38 & 1.09 & 3.03 & 0.39 & 429 & 0.56 & 220 & 28 & 0.26 & 4.12 \\
\hline 1980 & 2.01 & 1.80 & 4.36 & 0.41 & 435 & 0.67 & 270 & 37 & 0.29 & 6.16 \\
\hline 2028 & 2.64 & 3.34 & 5.43 & 0.33 & 433 & 0.63 & 255 & 37 & 0.38 & 8.77 \\
\hline 2100 & 2.48 & 3.62 & 5.96 & 0.22 & 435 & 0.67 & 271 & 28 & 0.38 & 9.58 \\
\hline 2133 & 3.01 & 3.79 & 6.01 & 0.53 & 434 & 0.65 & 262 & 26 & 0.39 & 9.80 \\
\hline 2181 & 2.66 & 3.54 & 5.78 & 0.27 & 436 & 0.69 & 280 & 21 & 0.38 & 9.32 \\
\hline
\end{tabular}

Table 2. Results of n-alkanes, isoprenoids, terpanes and steranes molecular parameters measured for the samples

\begin{tabular}{|c|c|c|c|c|c|c|c|c|c|c|c|}
\hline $\begin{array}{c}\text { Sample } \\
\text { I. D }\end{array}$ & $\begin{array}{c}\mathrm{Pr} / \\
\mathrm{Ph}\end{array}$ & $\begin{array}{c}\mathrm{Pr} / \\
n \mathrm{C}_{17}\end{array}$ & $\begin{array}{c}\mathrm{Ph} / \\
n \mathrm{C}_{18}\end{array}$ & $\mathrm{CPI}$ & $\begin{array}{c}\mathrm{Ts} / \\
\mathrm{Ts}+\mathrm{Tm}\end{array}$ & $\begin{array}{c}\mathrm{C} 31 \alpha \beta \\
\text { Hopane }\end{array}$ & $\begin{array}{c}\mathrm{C} 29 \alpha \alpha \alpha \\
\text { Sterane }\end{array}$ & $\begin{array}{c}\% \\
\mathrm{C} 27\end{array}$ & $\begin{array}{c}\% \\
\mathrm{C} 28\end{array}$ & $\begin{array}{c}\% \\
\mathrm{C} 29\end{array}$ & $\begin{array}{c}\% \\
\mathrm{C} 30\end{array}$ \\
\hline $\mathrm{Ar}-88$ & 0.8 & 0.5 & 0.2 & 1.1 & $\mathrm{n} . \mathrm{m}$ & $\mathrm{n} . \mathrm{m}$ & 0.09 & 54 & 17 & 29 & $\mathrm{n} . \mathrm{m}$ \\
\hline $\mathrm{Ar}-145$ & 0.9 & 1.1 & 0.8 & 0.9 & 0.18 & 0.18 & 0.05 & 49 & 30 & 21 & 6.0 \\
\hline $\mathrm{Ar}-148$ & 0.7 & 0.6 & 0.7 & 2.3 & 0.15 & 0.15 & 0.13 & 59 & 23 & 18 & $\mathrm{n} . \mathrm{m}$ \\
\hline $\mathrm{Ar}-149$ & 1.2 & 1.2 & 0.7 & 1.5 & 0.19 & 0.18 & 0.11 & 51 & 25 & 24 & 3.6 \\
\hline $\mathrm{Ar}-151$ & 0.7 & 0.5 & 0.5 & 0.9 & 0.43 & 0.46 & 0.22 & 54 & 27 & 19 & 2.7 \\
\hline
\end{tabular}

\subsubsection{Quantity of Organic Matter}

The data showed that TOC range from $0.74 \mathrm{wt} . \%$ to $3.01 \mathrm{wt} . \%$ with an average of $1.85 \mathrm{wt} . \%$ within the Araromi Formation. Also, the $\mathrm{S}_{2}$ value range from 3.03 to $6.01 \mathrm{mg} \mathrm{HC/} \mathrm{g} \mathrm{rock} \mathrm{with} \mathrm{average} \mathrm{of} 4.51 \mathrm{mg} \mathrm{HC/g}$ rock. The 
TOC is the mass of carbon per unit mass of the whole rock determined by summing the carbon in the pyrolyzate $\left(\mathrm{S}_{1}, \mathrm{~S}_{2}\right.$ and $\left.\mathrm{S}_{3}\right)$ with the carbon obtained by oxidizing the residual organic matter after heating to $650^{\circ} \mathrm{C}$ (Peters, 1986). The $S_{2}$ is the amount of hydrocarbon (mg HC/g rock) liberated by thermal degradation of the kerogen in the rock at temperature between $300-550^{\circ} \mathrm{C}$. This work utilized Peter and Cassa (1994) classification of organic richness in source rock with respect to TOC and $S_{2}$ values (Fig. 6). The data points range from fair to very good zone of source rock quantity. The TOC in the lower part of the Araromi formation are relatively higher than the TOC from middle and upper part. An explanation to this is that the base of Araromi formation uncomformably overlain the deep-seated bitumen rich Turonian - Coniacian sediment, which is believed to be a contributing factor to its relatively higher TOC.

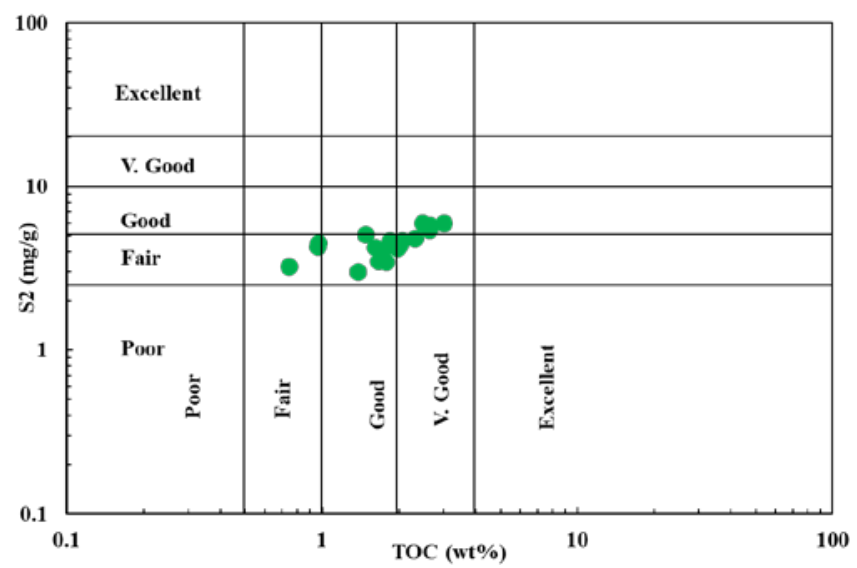

Fig. 6. Quantity and quality of organic matter in the studied wells from TOC and S2 analysis

\subsubsection{Types of Organic Matter}

The precursor(s) (type) of organic matter preserved in these shale samples as well as the depositional conditions (redox potential) were examined through the integration of a battery of molecular geochemical parameters ranging from pyrolysis biomarker data.

The hydrogen index (HI) values range from 196 to $280 \mathrm{mg}$ HC/gTOC with an average of $244 \mathrm{mg} \mathrm{HC/gTOC}$ and the oxygen index range from 21 to $46 \mathrm{mg} \mathrm{CO} /$ gTOC with an average of $33 \mathrm{mg} \mathrm{CO} /$ gTOC. The nature of organic matter making up the source rock is a useful tool in determining the oil and gas potential of the source rock. Espitalie et al., 1977 classified kerogen types using pyrolysis data because they were not controlled by organic matter abundance, instead, they are influenced by the elemental composition of kerogen. They classified kerogen types with a modified Van Krevelen diagram 
by substituting $\mathrm{H} / \mathrm{C}$ with $\mathrm{HI}$ and $\mathrm{O} / \mathrm{C}$ with $\mathrm{OI}$ data from the pyrolysis. On the modified diagram, Type I kerogens are characterized with relatively high HI and low OI, Type III kerogens have relatively low HI and high OI, and Type II kerogen are intermediate. In the plot of HI vs. OI (Fig. 7), all the data points fall within the lower limits of the Type II zone. In addition, the Langford and Blanc-Valleron (1990) plot was also used to determine the genetic type of organic matter. Based on this TOC vs $S_{2}$ cross plot (Fig. 8), all the data points are within the type II-III zone except for two data points in the type II zone. The results showed that Araromi source rock are dominated by marine algae materials with some terrestrial influence. The HI range of 196 to 280 mgHC/gTOC also falls within the Waples (1985) Type II classification.

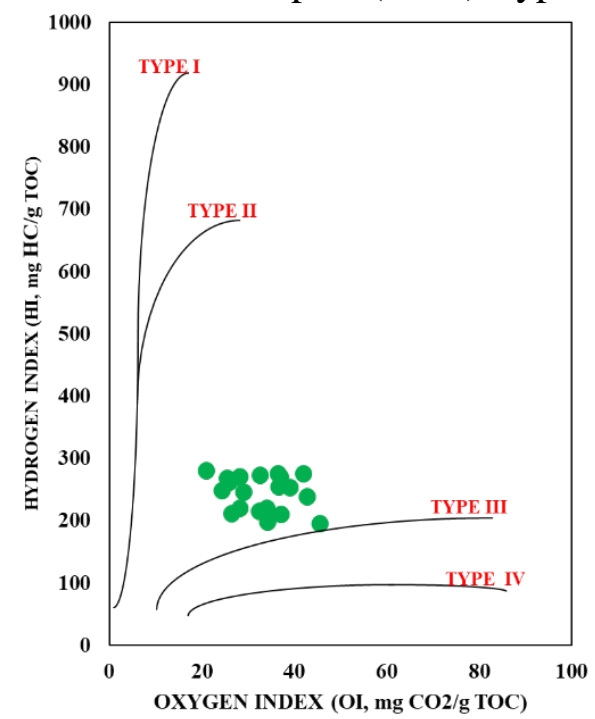

Fig. 7. Organic matter types within Araromi Formation source rock as indicated from OI and $\mathrm{HI}$ 


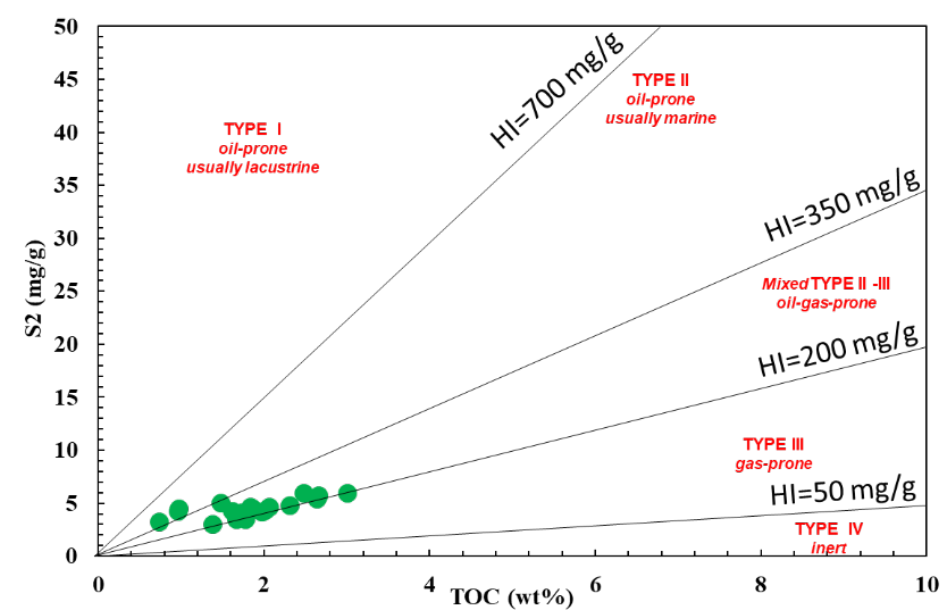

Fig.8. Cross plot of $S_{2}$ and Toc for determining kerogen types

\section{n- Alkanes Distribution}

Bray and Evans (1961) have shown that the normal alkane (n-alkane) chain length is a function of the type of fatty acid synthesized biologically. Marine algae make shorter $n$ - alkane chains than terrigenous higher plants. Because of this, most algae and bacterial derived $n$-alkane usually show a maximum between $n \mathrm{C}_{17}$ and $n \mathrm{C}_{21}$, while terrigenous higher plants typically produce $n$-alkanes that maximizes around $n \mathrm{C}_{29}$. Most of the samples analysed by GC display a bi-modal $n$-alkane envelope with maxima between $n \mathrm{C}_{16}$ and $n \mathrm{C}_{18}$, and $n \mathrm{C}_{27}$ and $n \mathrm{C}_{29}$ respectively (Fig. 9), suggesting that the source organic matter have been derived from a variable mixture of algae and terrigenous higher plants materials. However, sample Ar-145 (Fig. 10) display an almost unimodal $n$-alkane profile typical of a dominantly normal marine algal contribution (i.e. maximizing between $n \mathrm{C}_{16}-n \mathrm{C}_{18}$ ) (Jacobson et. al., 1998).

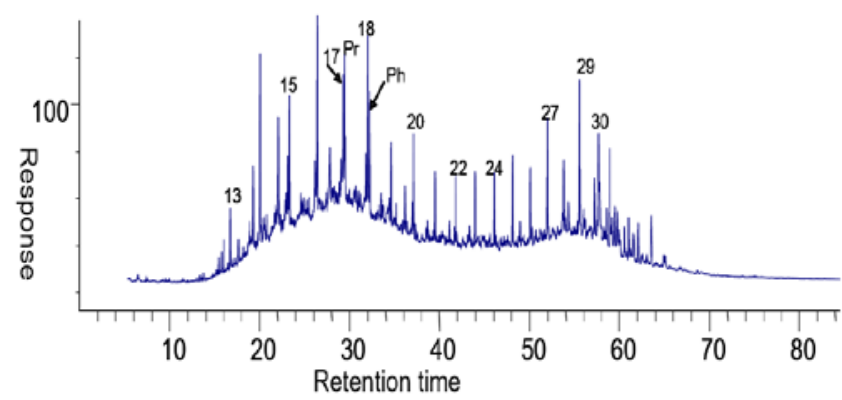

Fig. 9. A bimodal $n$ - alkane envelope of sample Ar- 149 maximizing at $n \mathrm{C}_{16}$ and $n \mathrm{C}_{29}$ typical of source rock whose organic matter have been derived from a variable mixture of algal and 
terrigenous higher plant materials. Note 13,15 , etc. represents the $n$-alkane carbon numbers and Pr; pristane, Ph; phytane

$\mathrm{Fi}$

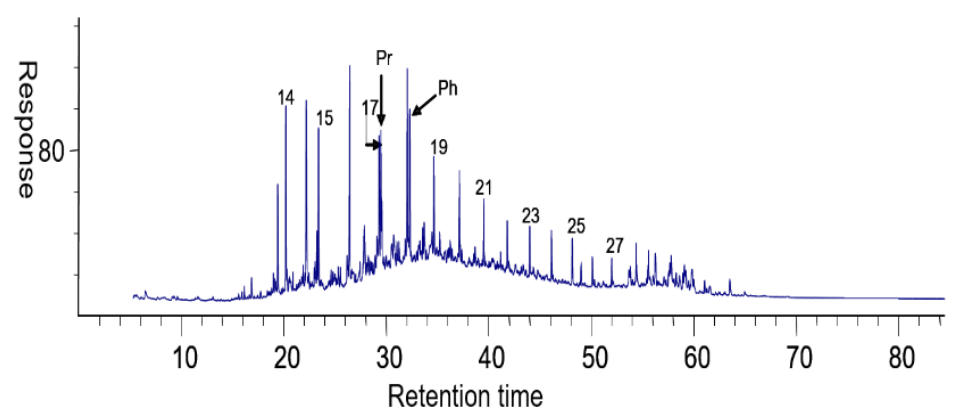

Fig. 10. A unimodal $n$ - alkane envelope of sample Ar-145 maximizing at $n \mathrm{C}_{16}$ typical of a dominantly marine algae contribution to the organic matter. Note 14,15, etc. represents the $n$-alkane carbon numbers

The calculated carbon preference index which measures the proportion of the odd to even-carbon numbered $n$-alkane $\left(\mathrm{CPI}_{1}\right.$ in the range $n \mathrm{C}_{24}-n \mathrm{C}_{34}$; Bray \& Evans, 1961) ranges in value from 0.9 - 1.1 for most samples except for sample Ar-148 and Ar-149. This general CPI range is indicative of a dominantly marine algae contribution to the source organic matter for these samples (Scalan \& Smith, 1970). This inference of a significant marine algal derived organic matter is further strengthened by the sterane carbon distribution as discussed in the later sub-section.

\section{Sterane Carbon Distribution}

On the basis of differences in the source of cholestane $\left(\mathrm{C}_{27}\right.$ sterane derived mainly from marine red algae), ergostane $\left(\mathrm{C}_{28}\right.$ sterane derived predominantly from algae of marine and or lacustrine ecology) and stigmastane $\left(\mathrm{C}_{29}\right.$ sterane derived predominantly from higher plants and a few non-marine green and brown algae), the relative abundances of these sterane compounds in sediment EOM and crude oil have always been used as a proxy for level of contribution of their precursors to the source organic matter (Moldowan et. al., 1985). From the sterane carbon distribution as shown in the ternary plot (Fig. 11), most samples contain dominantly of the $\mathrm{C}_{27}$ sterane and less than $30 \%$ of $\mathrm{C}_{29}$ sterane, suggesting a relatively higher input from the marine red algae and a low level of land plant contribution to the source organic matter (Goodwin, 1973). All the steranes have similar distributions in the studied wells (C27>C28>C29) as seen in Table 2. 


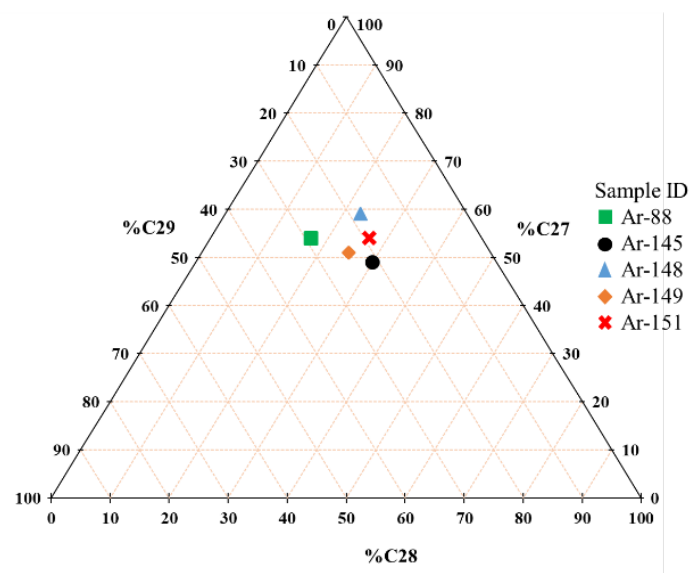

Fig. 11. A triplot of the sterane carbon number distribution using the $\% C_{27}, \% C_{28}$ and the $\% \mathrm{C}_{29} \alpha \alpha \alpha \mathrm{R}$ steranes from m/z 217 mass chromatogram. Data plot show that all of the samples contain less than $30 \%$ of $\mathrm{C}_{29}$ sterane; this suggests a low level of land plant contribution to the source organic matter

\section{C30 Sterane}

Sterane containing 30 carbon atoms i.e. 24-n-propylcholestane has been shown to be derived predominantly from the $\mathrm{C}_{30}$ sterol of the lipid membrane of marine chrysophyte algae (Rohmer et. al., 1980). By extension of this reasoning, the occurrence of $\mathrm{C}_{30}$ sterane in the Araromi samples (Fig. 11) has been investigated and representative samples contain measurable amount (Table 2). This suggests a marine origin for the source rock kerogen.

\section{Triterpanes}

Although the samples are immature, their triterpane distributions offer an excellent opportunity to corroborate the previous assertion that there is generally a very low level of land plant contribution (app. 30\% $\mathrm{C}_{29}$ sterane in all) to the sedimentary organic matter for all of these samples. The absence of oleanane (a biomarker highly diagnostic of angiosperm land plant) in all of the samples suggests a restricted land plant contribution (Ekweozor and Udo, 1988). Although abundant oleanane occurrence has also been shown to be restricted to sediments not older to Late Cretaceous (Moldowan et. al., 1994). This observation of an absence of an oleanane peak in the m/z 191 of all of the samples analysed in this Araromi shale samples set is consistent with the findings of Ekweozor and Udo (1988) who first reported the paucity of oleanane in Abeokuta Group shale samples. The absence of oleanane has been attributed probably to the separation of the Anambra and Dahomey epeiric seas by Okitipupa ridge during the Upper Cretaceous thus giving rise to the 
restriction of oleananes (angiosperm precursors) to the south-eastern Nigerian sedimentary basins and their absence in the south-western Dahomey Basin (Ekweozor and Udo, 1988).

\subsubsection{Thermal Maturity of Organic Matter Tmax}

The thermal maturity is determined from Tmax, the temperature at which the $\mathrm{S}_{2}$ peak is maximum. The value ranges from $418^{\circ} \mathrm{C}$ to $436^{\circ} \mathrm{C}$ with an average of $429^{\circ} \mathrm{C}$ in the Araromi well. Thermal maturity describes the overall temperature influence that converts organic matter in sedimentary rocks to petroleum products. They are classified into immature, mature and post mature with regards to temperature (Peter and Cassa, 1994). The nature of organic matter and extent of thermal maturity controls type and distribution of petroleum products within a given source rock (Tissot and Welte 1984, Langford and Blanc-Valleron 1990). Tmax is influenced by the type of organic matter and show relatively higher values in marine and lacustrine organic matter (Tissot and Welte 1984). Peter and Cassa 1994, Hunt (1996) identified the various Tmax ranges for different stages of maturity in a source rock. They are $<435^{\circ} \mathrm{C}$ for immature rocks, $435^{\circ} \mathrm{C}-470^{\circ} \mathrm{C}$ for the mature zones and $>470$ ${ }^{\circ} \mathrm{Cfor}$ post mature. The Tmax values in this well are all below the $435^{\circ} \mathrm{C}$ maturity cut-off except for three data points in the lower part of the well (Fig. 12).

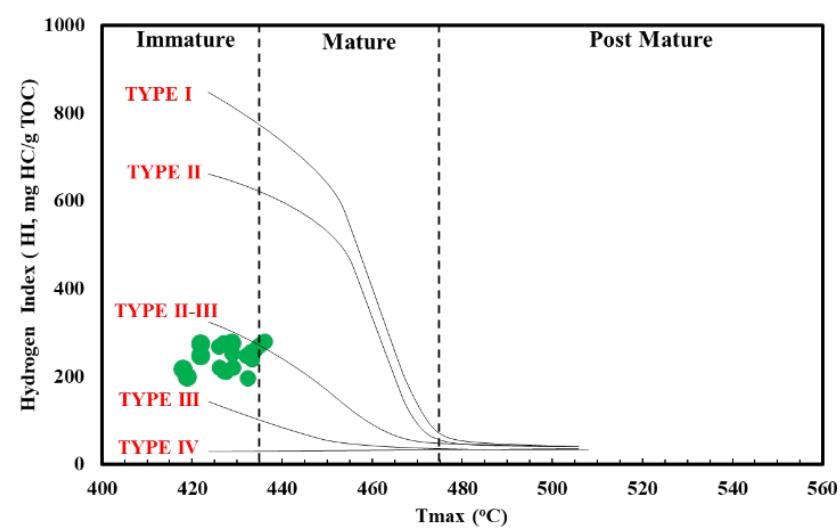

Fig. 12. Thermal maturation and types of organic matter from Tmax and HI

Further maturation indices of Hopanes and steranes isomerisation maturity parameters were calculated from integrated peak heights in the $\mathrm{m} / \mathrm{z}$ 191 for hopanes and m/z 217 mass chromatogram for sterane. Values for the measured thermal maturity parameters are presented in Table 2. The samples are generally immature (very low values generally less than 0.25 ) except for sample Ar-151 which is mature for the measured parameters. In general, there 
is a good agreement among the calculated Ts/Tm, $\mathrm{C}_{31} \alpha \beta$ Hopane and the $\alpha \alpha \alpha$ $\mathrm{C}_{29}$ sterane maturity parameters for the samples. $\alpha \beta \beta \mathrm{C}_{29}$ sterane maturity parameter could not be calculated because of their low concentration at this thermal level for the samples. Fig. 13 is an m/z 191 mass chromatogram showing a representative distribution of the terpenoids in sample Ar-I45.

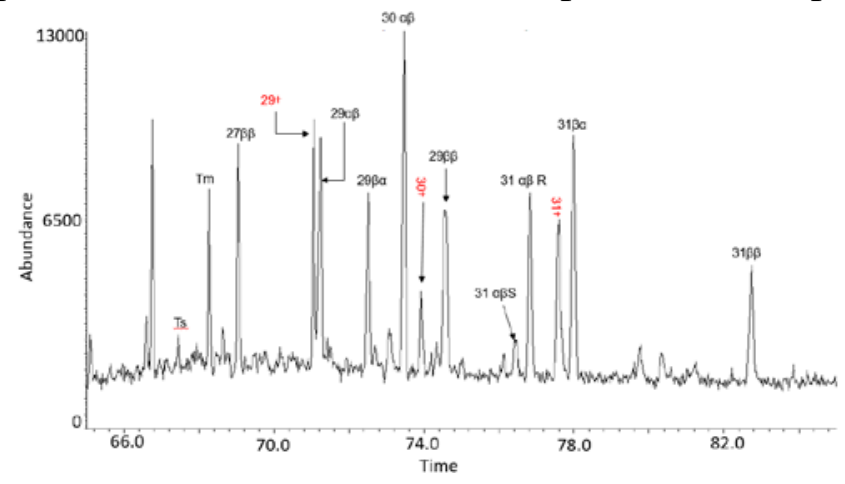

Fig. 13. $\mathrm{m} / \mathrm{z} 191$ mass chromatogram of sample Ar-145 showing the terpenoids distribution. Numbers refer to carbon numbers. $\beta \beta, \beta \alpha, \alpha \beta$, refer to the stereochemistry at the 14 and 21 carbon number respectively in the hopanes structure. Labels in red (e.g. 29†) are Hopenes.

Ts and Tm refer to $17 \alpha(\mathrm{H}), 22,29,30$-trisnorhopane and $18 \alpha(\mathrm{H}), 22,29,30-$ trisnorneohopane respectively. Compounds have been identified by TIC GC- MS and by GC-MS/MS parent to daughter ion transition

\subsection{Conclusions}

The following conclusions can be drawn from this study:

- The Araromi Shale in the study area are dominated by organic matter that are $<3$ wt.\% TOC, with the highest values from samples at the base of the formation.

- The source rock is made up of Type II kerogen, further classification scheme showed they are mainly Type II-III

- The samples from AGB-1 well are generally immature, only samples that are believed to be influenced by the underlying bitumen reached the $435^{\circ} \mathrm{C}$-maturity cutoff. Also, Hopanes and steranes isomerisation maturity parameters in studied samples showed the that the Araromi shale is immature except for sample Ar-151

- $n$ - Alkanes distribution showed bimodal signature between $n \mathrm{C}_{16}-n \mathrm{C}_{18}$ and $n \mathrm{C}_{27}-n \mathrm{C}_{29}$ with a unimodal $n \mathrm{C}_{16}-n \mathrm{C}_{18}$ signature suggesting variable mixture of marine algae and terrigenous higher plants materials. The inference of a significant marine algal derived organic matter is further strengthened by the $\mathrm{C} 27>\mathrm{C} 28>\mathrm{C} 29$ sterane carbon distribution 
- Triterpanes studies showed that the absence of oleanane (a biomarker highly diagnostic of angiosperm land plant) in all of the samples suggests a restricted land plant contribution

- Pristane/phytane ratio suggested that the organic matter type is dominantly Type II/III with an anoxic source rock depositional condition as well as a reducing diagenetic system in the sediment water column. The reducing diagenetic system is also supported with the presence of high Sulphur content.

- Biostratigraphy data suggested a shallow marine environment due to the dominance of benthonic foraminifera species. Also, the percentage of calcareous to arenaceous benthic foraminifera in the well is relatively high and this is an indication high water salinity and hypersaline environment. The oxygen condition suggests a dysoxic condition because most of the benthic foraminifera recovered are epifauna that live in a reduced oxygen condition

- The overall assessment reveals that the Upper Cretaceous shale in this study and other previous work is some potential resources for unconventional hydrocarbon exploration

\section{Appendix}

TOC - Total Organic Carbon, wt. \%

$\mathrm{S}_{1}$ - volatile hydrocarbon (HC) content, mgHC/grock

$\mathrm{S}_{2}$ - remaining $\mathrm{HC}$ generative potential, mgHC/grock

$\mathrm{S}_{3}$ - carbon dioxide content, $\mathrm{mg} \mathrm{CO}_{2} / \mathrm{g}$ rock

Tmax ${ }^{\circ} \mathrm{C}$ - Maximum $\mathrm{S}_{2}$ Temperature

Ro - Vitrinite reflectance

HI - Hydrogen index $=\mathrm{S}_{2} \times 100 /$ TOC, mgHC/gTOC

OI - Oxygen Index $=\mathrm{S}_{3} \mathrm{x} 100 / \mathrm{TOC}, \mathrm{mgCO}_{2} / \mathrm{gTOC}$

PI - Production Index $=\mathrm{S}_{1} /\left(\mathrm{S}_{1}+\mathrm{S}_{2}\right)$

$\mathrm{S}_{1}+\mathrm{S}_{2}$ Generating Potential (HC) content, mg HC/grock

$\mathrm{Pr} / \mathrm{Ph}$ : ratio of Pristane to Phytane calculated as the ratio of their peak heights from the GC mass chromatogram;

$\mathrm{Pr} / n_{\mathrm{C} 17}, \mathrm{Ph} / n \mathrm{C}_{18}$ : ratio of peak heights of pristane $/ n \mathrm{C}_{17}$ and phytane $/ n \mathrm{C}_{18}$ from the GC mass chromatogram;

Ts/ Ts +Tm: peak height of $18 \alpha(\mathrm{H}), 22,29$, 30-trisnorneohopane/18 $\alpha(\mathrm{H}), 22$, 29, 30-trisnorneohopane $(+) 17 \alpha(\mathrm{H}), 22,29,30$-trisnorhopane (from m/z 191 mass chromatogram);

$\mathrm{C}_{31} \alpha \beta$ 22S $/ \mathrm{C}_{31} \alpha \beta(22 \mathrm{~S}+22 \mathrm{R})$ hopane: $17 \alpha(\mathrm{H}), 21 \beta(\mathrm{H})$-homohopane 22S/22S+22R (from m/z 191 mass chromatogram); 
$\mathrm{C}_{29} \alpha \alpha \alpha \mathrm{S} / \mathrm{C}_{29} \alpha \alpha \alpha(\mathrm{S}+\mathrm{R}): 5 \alpha(\mathrm{H}), 14 \alpha(\mathrm{H}), 17 \alpha(\mathrm{H})$-stigmastane 20S/ 20S+20R (from m/z 217 mass chromatogram);

$\% \mathrm{C}_{27}, \% \mathrm{C}_{28}, \% \mathrm{C}_{29}$ steranes: peak height of the $\mathrm{R}$ epimer of the sterane carbon number as a percentage of the sum of $\mathrm{C}_{27} \mathrm{R}-\mathrm{C}_{29} \mathrm{R}$ steranes from m/z 217 mass chromatogram;

$\% \mathrm{C}_{30}$ : peak height of the $\mathrm{R}$ epimer of the $\mathrm{C}_{30}$ sterane carbon number as a percentage of the sum of $\mathrm{C}_{27} \mathrm{R}-\mathrm{C}_{30} \mathrm{R}$ steranes from $\mathrm{m} / \mathrm{z} 217$ mass chromatogram; n.m. refers to samples that are not measurable for a particular parameter because of weak signal of a particular peak.

\section{Acknowledgement}

The Authors of this work wishes to appreciate the efforts of Professor Stephan Nordeng and Miss Chioma Onwumelu at the University of North Dakota Geology department for assisting with rock Eval pyrolysis analysis. Also, we appreciate Prof. Peter Prinz-Grimm and Prof. Jens Herlle both at the Johann Wlfgang Universitat am Main, Frankfurt, Germany, Department of Geology and Geophysics. The authors would also like to thank Dr. Holger Gebhardt for his assistance during the laboratory work.

\section{References:}

1. Abacan-Addax Consortium (1998). Ise Hydrocarbon Potential - Benin Offshore Block 1, Report, 113 p.

2. Adegoke, O. S. (1969). Eocene stratigraphy of southern Nigeria." Colloque sur l'Eocene. Vol. 3.

3. Adegoke, O. S. (1977). Stratigraphy and paleontology of the Ewekoro Formation (Paleocene) of southwestern Nigeria. Paleontological Research Institution.

4. Adegoke, O. S., Jeje, L. K., Durotoye, B., Adeleye, D. R., and Ebukanson, E. E. (1980). The Geomorphology and aspects of sedimentology of coastal region of Western Nigeria. Journal of Mining and Geology, 17, 217-223.

5. Adekeye, O. A., Gebhardt, H., Akande, S. O., Adeoye, J. A., Abdulkadir, I. A., (2019). Biostratigraphic Analysis of the Cretaceous Abeokuta Group in the Eastern Dahomey Basin, Southwestern Nigeria. Journal of African Earth Sciences 169103887. https://doi.org/10.1016/j.jafrearsci.2020.103887.

6. Adekeye, O.A and Akande, S.O. (2010). The principal source rocks for petroleum generation in the Dahomey Basin, Southwestern Nigeria. Continental J. Earth sciences 5(1): 42-55 
7. Adekeye, O.A. (2005). Aspects of sedimentology, geochemistry and hydrocarbon potentials of Cretaceous-Tertiary sediments in the Dahomey Basin, south-western Nigeria. Unpublished Ph.D. thesis, University of Ilorin, 202p.

8. Adekeye, O. A., Akande, S. O., Erdtmann, B.D., Samuel, O. J. and Hetenyi, M. (2006). Hydrocarbon Potential Assessment of the Upper Cretaceous-Lower Tertiary Sequence in the Dahomey Basin Southwestern Nigeria. NAPE Bulletin. v. 19 No 1, p.50-60.

9. Adeoye, J. A., Akande S. O., Adekeye, O. A., Sonibare W. A., Ondrak R., Dominik W., Erdtmann B. D. and Neeka J. (2020). Source Rock Maturity and Petroleum Generation in the Dahomey Basin SW Nigeria: Insights from Geologic and Geochemical Modelling. Journal of Petroleum Science and Engineering 195 (2020) 107844. https://doi.org/10.1016/j.petrol.2020.107844.

10. Ako, B. D., O. S. Adegoke, and S. W. Petters (1980). "Stratigraphy of the Oshosun formation in southwestern Nigeria." Jour. Min. Geol 17: 9-106.

11. Beicip-Franlab (1994). Etude Géologique et Evaluation des Réserves du Champ de Sèmè, Rapports Vol. I, 157 p. et Vol. II, 128 p.

12. Bernhard, J. M., (1986), Characteristic assemblages and morphologies of benthic foraminifera from anoxic, organic rich deposits: Jurassic through Holocene. Journal of Foraminifera Research v. 16, p. 207 215.

13. Billman, H.G., (1976). Offshore stratigraphy and paleontology of the Dahomey embayment. Proceedings of the 7th African Micropaleontological Colloquium, March 16-28, 1976, Ile-Ife, Nigeria, pp: 27-42.

14. Bray, E.E. \& Evans, E.D. (1961). Distribution of n-paraffins as a clue to recognition of source beds. Geochimica et Cosmochimica Acta, 22, 2-5.

15. Brownfield M.E., Charpentier R.R. (2006). Geology and total petroleum systems of the West-Central Coastal Province (7203), West Africa, U.S. Geological Survey Bulletin 2207-C, 52 p.

16. Burke K., Dessauvagie T.F.J., Whitman A.J. (1971). Opening of the Golf Gulf of Guinea and geological history of the Benue depression and Niger delta, Nature Phys. Sci. 233, 38, 51-55.

17. Clementz, D. M., Demaison, G. J., and Daly, A. R. (1979). Well site geochemistry by programmed pyrolysis. In Offshore Technology Conference. Offshore Technology Conference. 
18. Didyk, B. M., Simoneit, B. R. T., Brassell, S. C. and Englinton, G. (1978). Organic geochemical indicators of paleoenvironmental conditions of sedimentation. Nature, 272, 216-222.

19. Ekweozor, C. M., and Udo O. T. (1988). The oleananes: Origin, maturation, and limits of occurrence in Southern Nigeria sedimentary basins, In L. Mattavelli, and L. Novelli, (editors), Advances in Organic Geochemistry 1987, Organic Geochemistry, 13, Pergamon Press, p. 131-140.

20. Ekweozor, C. M., and Telnaes. N. (1990). Oleanane parameter: verification by quantitative study of the biomarker occurrence in sediments of the Niger delta. Organic Geochemistry 16.1-3 401-413.

21. Ekweozor, C.M., and Nwachukwu, J. L., (1989). The origin of tar sands of SouthWestern Nigeria. N.A.P.E. Bull. Vol.4 No 2, pp 82-84.

22. Elvsborg, A., and J. Dalode (1985). Benin hydrocarbon potential looks promising. OIL \& GAS JOURNAL 83. 6: 126.

23. Enu, E. I. (1987). The Paleoenvironments of deposition of Late Maastrichtian to Paleocene black shales in eastern Dahomey Basin. Nigeria Geog. Mijnbouw, 66: 15-20

24. Espitalie, J., Madec, M., Tissot, B., Menning, J. J., and Leplat, P. (1977). Source rock characterization method for petroleum exploration. In Offshore Technology Conference. Offshore Technology Conference.

25. Gebhardt, H., (1998). Benthic Foraminifera from the Maastrichtian Lower Mamu Formation near Leru (Southwestern Nigeria): Paleoecology and Paleogeographic Significance. Department of geology and Mineral Sciences, University of Ilorin Journal of Foraminifera Research, v. 28, no. 1, p. 76 - 89, January 1998.

26. Gebhardt, H., (2004). Planktonic Foraminifera of the Nkalagu Formation Type Locality (southern Nigeria, Cenomanian to Coniacian): biostratigraphy and Paleoenvironmental Interpretation. Cretaceous Research. v. 25, issue 2, p. 191 - 209 https://doi.org/10.1016/j.cretres.2003.11.003

27. Goodwin, T. W. (1973). Comparative Biochemistry of Sterols in eukaryotic Microorganisms, In J. A. Erwin, (editor) Lipids and biomembranes of eukaryotic microorganisms. New York, Academic Press, p. 1-40.

28. Hessouh M., Marcos I., Pereira J. J., Farhangui H.J. (1994). Hydrocarbon Prospects for Exploration and Production, Report, 88 p.

29. Hunt, J. M. (1996). Petroleum geochemistry and geology (Vol. 2, pp. 1-743). New York: WH Freeman. 
30. Idowu, J. O., Ajiboye, S. A., Ilesanmi, M. A. and Tanimola, A. (1993). Origin and significance of organic matter of Oshosun Formation southwestern Dahomey Basin Nigeria. Jour. Min. Geol. v. 29, p. 9-17.

31. Jacobson, S. R., Hatch, J. R. and S.C, T. (1988). Middle Ordovician organic matter assemblages and their effect on Ordovician - derived oils. American Association of Petroleum Geologists, 72, 1090-100.

32. Jan Du Chene, R. E (1977). "Some new pollen species of the upper Maastrichtian, Tar Sand, Abeokuta formation, southern Nigeria." Revista Espanola De Micropaleontologia 9. 2: 191-201.

33. Kaiho, K. (1999). Global climatic forcing of deep-sea benthic foraminiferal test size during the past 120 m.y. Geology, 26 (6), 491494.

34. Kingston, D. R., Dishroon, C. P. and P. A. Williams. (1983) "Hydrocarbon plays and global basin classification." AAPG Bulletin 67.12 2194-2198.

35. Klemme, H.D., (1975) Geothermal Gradients, Heat flow and Hydrocarbon Recovery. In: A.G. Fischer and S. Judson (eds), Petroleum and Global Tectonics. Princeton, New Jersey, Princeton Univ. Press, pp. 251- 304

36. Kogbe, C. A (1974). "The upper Cretaceous Abeokuta formation of south-western Nigeria." Nigerian Field 4, 47.

37. Langford, F. F., and Blanc-Valleron, M-M. (1990). "Interpreting Rock-Eval pyrolysis data using graphs of pyrolyzable hydrocarbons vs. total organic carbon (1)." AAPG Bulletin 74.6 (1990): 799-804.

38. Moldowan, J. M., Seifert, W. K. and Gallegos, E. J. (1985). Relationship between petroleum composition and depositional environment of petroleum source rocks. American Association of Petroleum Geologists, 69, 1255-1268.

39. Moldowan, J.M., Huizinga, B.J., Dahl, J.E., Fago, F.J., Taylor, D.W. \& Hickey, L.J. (1994). The molecular fossil record of oleanane and its relationship to angiosperms. Science, 265, 768-771.

40. Mpanda, S. (1997). Geological development of East African coastal basin of Tanzania: Acta Universities Stockholmiensis, v. 45, 121p.

41. Murray, J.W. and Wright, C.A. (1974). Palaeogene Foraminiferida and palaeoecology, Hampshire and Paris Basins and the English Channel. The Palaeontological Association, London, 14:1-171

42. Ogbe, F. G. A (1970). "Stratigraphy and paleontology of strata exposed in the Ewekoro quarry, Western Nigeria." Unpublished M. Phil. Dissertation, University of Ife, IIe-Ife, Nigeria (1970): 1-110. 
43. Okosun, E. A (1990). "A review of the Cretaceous stratigraphy of the Dahomey Embayment, West Africa." Cretaceous Research 11.1 (1990): 17-27.

44. Omatsola, M., and Adegoke, O. S., (1981). Tectonic evolution and Cretaceous stratigraphy of the Dahomey Basin: Journal of Mining and Geology, v. 18, no. 1, p. 130-137.

45. Peters K.E. (1986). Guidelines for evaluating petroleum source rock using programmed pyrolysis: American Association of Petroleum Geologists Bulletin, 70, pp. 318-329.

46. Peters, K. E., and Cassa, M. R. (1994). Applied source rock geochemistry: Chapter 5: Part II. Essential elements. The Petroleum System - From Source to Trap, AAPG Memoir 60 (1994) 93 - 120.

47. Peters, K.E., Walters, C.C. and Moldowan, J.M. (2005). The Biomarker Guide. Cambridge University Press. 2nd Edition. Volume 1, p. 79.

48. Rohmer, M., Kokke, W.C.M.C., Fenical, W. and Djerassi, C. (1980). Isolation of two new C30 sterols, (24E)-24-n-propylidenecholesterol and 24(E)-24-n-proprylcholesterol from a cultured marine chrysophyte. Steroids. 35, 219-231.

49. Scalan, R. S. and Smith, J. E. (1970). An improved measure of the oddto-even predominance in the normal alkanes of sediments extracts and petroleum. Geochimica et Cosmochimica Acta, 34, 611-620.

50. Storey, B. C. (1995). The role of mantle plumes in continental break up: case history from Gondwanaland - Nature, v. 377, p. 301-308.

51. Tissot, B. P., and Welte. D. H. (1984). "Petroleum Formation and Occurrence, 2nd edn, 699 pp."

52. Volkman J.K. and Maxwell, J.R (1986). Acyclic isoprenoids as biological markers. In Biological markers in sedimentary record: R.B. Johns (ed), Elsevier, New York, p. 1-42.

53. Waples, D.W., (1985). Geochemistry in Petroleum Exploration: Boston, International Human Resources Development Corporation, $232 \mathrm{p}$. 